\title{
DON as a source of bioavailable nitrogen for phytoplankton
}

\author{
D. A. Bronk ${ }^{1}$, J. H. See ${ }^{2}$, P. Bradley ${ }^{1}$, and L. Killberg ${ }^{1}$ \\ ${ }^{1}$ Department of Physical Sciences, The College of William and Mary, Virginia Institute of Marine Science, P.O. Box 1346, \\ Gloucester Point, VA 23062, USA \\ ${ }^{2}$ Geo-Marine Inc., 2201 K. Avenue, Suite A2, Plano, TX 75074, USA
}

Received: 26 June 2006 - Published in Biogeosciences Discuss.: 7 August 2006

Revised: 19 March 2007 - Accepted: 26 April 2007 - Published: 24 May 2007

\begin{abstract}
Relative to inorganic nitrogen, concentrations of dissolved organic nitrogen (DON) are often high, even in regions believed to be nitrogen-limited. The persistence of these high concentrations led to the view that the DON pool was largely refractory and therefore unimportant to plankton nutrition. Any DON that was utilized was believed to fuel bacterial production. More recent work, however, indicates that fluxes into and out of the DON pool can be large, and that the constancy in concentration is a function of tightly coupled production and consumption processes. Evidence is also accumulating which indicates that phytoplankton, including a number of harmful species, may obtain a substantial part of their nitrogen nutrition from organic compounds. Ongoing research includes ways to discriminate between autotrophic and heterotrophic utilization, as well as a number of mechanisms, such as cell surface enzymes and photochemical decomposition, that could facilitate phytoplankton use of DON components.
\end{abstract}

\section{Introduction}

The largest pool of fixed nitrogen $(\mathrm{N})$ in most aquatic systems is dissolved organic N (DON, Bronk, 2002). This is true even in oligotrophic environments where primary production is limited by available $\mathrm{N}$. The persistence of DON in areas believed to be $\mathrm{N}$-limited led to the traditional dogma that DON is largely refractory and therefore unimportant to phytoplankton $\mathrm{N}$ nutrition. The second part of this DON dogma is that DON is used to fuel bacterial, rather than phytoplankton, production and does so with relatively long turnover times. The objective of this paper is to highlight recent work on DON composition and bioavailability that calls for discarding the traditional dogmas. Research has shown

Correspondence to: D. A. Bronk

(bronk@vims.edu) that even highly refractory compounds can be a source of bioavailable $\mathrm{N}$ to plankton as well as a vehicle to transport $\mathrm{N}$ through the estuarine systems. Recent findings and new approaches also indicate that DON fuels a significant amount of autotrophic production.

\section{Is DON largely refractory?}

\subsection{The black box of DON and the elusive doughnut}

In the ocean, concentrations of DON are generally highest within the euphotic zone and then decrease to a low and constant value deeper in the water column (e.g. Hansell et al., 1993; Libby and Wheeler, 1997; Church et al., 2002; reviewed in Bronk, 2002; Bronk and Ward, 2005). The DON pool is generally treated like a "black box", the composition of which is unknown but is expected to change over small space and time scales. One approach that has been used to characterize DON is size fractionation (e.g. Benner et al., 1992; Aluwihare et al., 1997; McCarthy et al., 1996; reviewed in Benner, 2002). Using an ultrafilter with a 1000 Dalton cutoff a number of researchers have collected sufficient high molecular weight (HMW) material for analysis. Recent investigations show that amide-linked $\mathrm{N}$ comprises the largest fraction of HMW DON (92\%) with the remaining $8 \%$ consisting of amines (Aluwihare et al., 2005). Humic substances, one of the least understood classes of aquatic DOM, are generally not detectable by NMR spectroscopy and therefore may represent a small proportion of HMW DON in marine systems (Repeta et al., 2002). In some estuarine and coastal systems, however, humics can contribute a significant fraction of measured DON (e.g. Alberts and Takács, 1999). For example, in the Savannah and Altamaha estuaries of coastal Georgia humics contributed an average of $70 \%$ of the DON pool over a three-year period (Bronk et al., unpublished data).

Published by Copernicus Publications on behalf of the European Geosciences Union. 
Another approach to characterizing DON is based on lability. In this sense, the largest fraction within the DON box likely includes the truly refractory components that persist in the environment for months to hundreds of years (reviewed in Bronk, 2002). Using terminology from the dissolved organic carbon (DOC) literature, a second fraction of the pool can be described as semi-labile (Carlson and Ducklow, 1995). This fraction likely includes compounds such as proteins, dissolved combined amino acids (DCAA), and amino polysaccharides, which turnover on annual time scales. Mixed in with the refractory background, however, are the "doughnuts" of the DON world - highly labile moieties including urea, dissolved free amino acids (DFAA), and nucleic acids (reviewed in Bronk, 2002). These doughnuts turnover on timescales of minutes for amino acids (e.g. Fuhrman, 1987) to days for urea (e.g. Bronk et al., 1998) and DNA (e.g. Jørgensen et al., 1993).

The bulk of research on DON availability has focused on the labile doughnut fraction. Recent work, however, has also shown that even HMW compounds such as humic substances, considered to be highly refractory, can be a source of $\mathrm{N}$ (i.e. See et al., 2006). Humics are operationally defined as DOM that adheres to a macroporous resin (i.e. XAD-8 or DAX-8; Peuravuori et al., 2002) at a pH of 2 (Aiken, 1988). They can be further categorized into 1) fulvic acids, which tend to be smaller (500-2000 Daltons) and are soluble in water at any pHs, 2) humic acids, which are larger (20005000 Daltons or larger) and precipitate from solution at $\mathrm{pH}$ lower than 2 (Thurman et al., 1982), and 3) humins, which are insoluble at any $\mathrm{pH}$.

Natural humic substances, isolated with XAD extraction, have been shown to contain 0.5 to $6 \% \mathrm{~N}$ (Rashid, 1985; Thurman, 1985; Hedges and Hare, 1987). Amino acids, amino sugars, ammonium $\left(\mathrm{NH}_{4}^{+}\right)$, and nucleic acid bases comprise 46 to $53 \%$ of the $\mathrm{N}$ associated with humic acids and 45 to $59 \%$ of fulvic acids (Schnitzer, 1985) with the remaining approximately $50 \%$ of humic-N unidentified (Carlsson and Granéli, 1993). Previous work indicates that the C to N (C:N) ratio of aquatic humic substances, isolated with XAD resin, ranges from 18 to $30: 1$ for humic acids and 45 to $55: 1$ for fulvic acids, but can vary considerably (Thurman, 1985; See, 2003; See and Bronk, 2005). The C:N of humic substances isolated with macroporous resins, however, may not reflect the $\mathrm{C}: \mathrm{N}$ ratios of humic substances in situ. During the isolation procedure humic substances are acidified to a $\mathrm{pH}$ of 2 , thus bombarding the solution with free protons. These free protons can bump off loosely associated amino groups such that humics isolated using resins have a $\mathrm{C}: \mathrm{N}$ ratio higher than humics in natural waters (See and Bronk, 2005).

\subsection{Results from bioassays}

The unknown composition of the bulk DON pool makes determining its bioavailability difficult. Isotopic tracers are currently available for only a small fraction of the pool. As a result, bioassay approaches have been used to monitor the decrease in DON concentrations over time. One difficulty with the bioassay approach is it requires the ability to measure relatively small concentration changes in a large pool. Bioassays also only measure net flux within a pool, such that even large DON uptake rates could be unmeasurable if rates of DON regeneration are also high. Despite these drawbacks, a number of studies have used dark bioassays in aquatic systems to measure heterotrophic bacterial utilization of DON. In general, this work suggests that 12 to $72 \%$ of the DON pool is bioavailable on the order of days to weeks (reviewed in Bronk, 2002). In the Delaware and Hudson Rivers, 40 to $72 \%$ of the DON was consumed during 10 to 15 day dark bioassays (Seitzinger and Sanders, 1997). In two streams in Sweden, 19 to $55 \%$ of the bulk DON was found to be bioavailable in short-term bioassays (Stepanauskas et al., 2000); only 5 to $18 \%$ of the DON was identified as urea, DCAA or DFAA indicating that bacteria also utilize additional organic N compounds. In the Gulf of Riga, $13 \%$ of the DON was bioavailable during 7 to 8 day bioassay experiments (Jørgensen et al., 1999).

In another study water samples were collected from rivers and estuaries along a continuum of anthropogenic modification (Wiegner et al., 2006). Dark bioassays were performed with a single bacterial inoculum to compare DON and DOC lability across a range of systems that varied with the amount of forest cover. As much as $40 \%$ of the DON was consumed over a 6 day incubation and up to $80 \%$ of the total $\mathrm{N}$ utilized by the inoculum was organic in form. These results show that classifying all DON as refractory clearly overlooks an important source of available $\mathrm{N}$ in the marine environment.

\subsection{The special case of humics}

The refractory nature of humic substances has also recently been challenged, and accumulating evidence indicates that coastal phytoplankton may have the ability to take up humic$\mathrm{N}$, either directly or after remineralization by bacteria (Carlsson et al., 1995, 1998, 1999). More recently, the uptake of laboratory-produced ${ }^{15} \mathrm{~N}$-labeled humic compounds by the $>0.7 \mu \mathrm{m}$ size fraction has been observed in both riverine and coastal ecosystems (Bronk et al., unpublished data), humic substances have been implicated as a potential source of $\mathrm{C}$ and $\mathrm{N}$ to the toxic dinoflagellate Alexandrium catenella (Doblin et al., 2000), and growth of another toxic dinoflagellate Alexandrium tamarense was shown to increase when exposed to humic substances (Gagnon et al., 2005). Uptake of humic-N into phytoplankton biomass was also measured directly using ${ }^{15} \mathrm{~N}$-labeled humic substances produced in the laboratory (See and Bronk, 2005). In this experiment, nonaxenic cultures of 17 recently isolated estuarine and coastal phytoplankton strains took up ${ }^{15} \mathrm{~N}$-labeled humic-N (See et al., 2006), however, high rates of humic-N uptake were not sustained over long periods of time suggesting that a finite pool of labile $\mathrm{N}$ is associated with these compounds (See et 
al., 2006). Two of the cultures examined were also available in axenic form. No uptake of ${ }^{15} \mathrm{~N}$-labeled humic-N was detected in the axenic cultures suggesting that in at least these two cultures, bacterial remineralization was required to make the humic-N bioavailable.

\subsection{Why should we care?}

In a review of DON in rivers, Seitzinger and Sanders (1997) estimate that 14 to $90 \%$ of the total $\mathrm{N}$ in a suite of rivers around the world is organic in form. This DON represents a large source of $\mathrm{N}$ to the coastal zone that is currently ignored in most $\mathrm{N}$ loading budgets. This is especially troubling when one considers that effluent from even the most efficient wastewater treatment plants contain approximately $285 \mu \mathrm{M} \mathrm{N}$ with roughly two thirds of the discharged $\mathrm{N}$ being organic in form (Pehlivanoglu and Sedlak, 2006). Its exclusion from loading budgets is based on the traditional view that DON is not bioavailable and therefore will not contribute to eutrophication. The brief review of recent studies above suggests that this traditional view is incorrect. Collectively, data from bioassays suggest that bioavailable DON can be utilized within estuaries with water residence times on the order of weeks to months. In systems where residence times are shorter, riverine DON will pass through the estuary and be a source of bioavailable $\mathrm{N}$ to coastal waters. Results from studies with individual organic compounds indicate that some fractions of DON have much quicker turnover times and consequently contribute to plankton nutrition even in systems with very short residence times. It is becoming increasingly evident that a significant fraction of DON is bioavailable and contributes to coastal eutrophication and, as such, should be included in $\mathrm{N}$ loading budgets.

\section{Are bacteria the primary users of DON?}

Phytoplankton DON use has traditionally been neglected in favor of the view that bacteria are the primary consumers of DON for a number of reasons. First, phytoplankton are known to have specific metabolic pathways for the uptake and assimilation of inorganic $\mathrm{N}$ substrates such as $\mathrm{NH}_{4}^{+}$and nitrate $\left(\mathrm{NO}_{3}^{-}\right.$, e.g. Syrett, 1988; Hildebrand, 2005; Hildebrand and Dahlin, 2000). We think it unlikely that a given phytoplankter would employ a large number of similar specific uptake mechanisms for the broad suite of organic substrates that exist in very low concentrations at any given time. Recently, however, the genome of a marine diatom, Thalassiosira pseudonana, was sequenced and this diatom was shown to possess plasma membrane amino acid transporters despite the fact that amino acids are present at low concentrations in the environment (Armbrust et al., 2004). These data are also consistent with early autoradiography studies that demonstrated diatom uptake of ${ }^{14} \mathrm{C}$-labeled amino acids (Wheeler et al., 1974, 1977).
Second, early studies of plankton uptake of ${ }^{14} \mathrm{C}$-labeled organics indicate that the labeled substrates ended up in the bacterial-size fraction and the assumption was made that the N followed the C. Stephens and North (1971), however, showed that $\mathrm{C}$ was excreted following amino acid uptake. Other researchers went on to show that some phytoplankton possess cell-surface enzymes that allow them to take up the $\mathrm{N}$ fraction of amino acids while leaving the $\mathrm{C}$ backbone available for subsequent uptake by bacteria (e.g. Palenik and Morel, 1990a and b); this mechanism was proposed as early as 1948 (Algeus, 1948). In other words, the $\mathrm{N}$ does not always follow C. The presence of these cell-surface enzymes provides a likely mechanism whereby phytoplankton can access a broad range of organic $\mathrm{N}$ substrates without developing a specific uptake pathway. This discovery merits a reevaluation of the dogma regarding phytoplankton use of DON. Here we review methods for distinguishing bacterial uptake from phytoplankton uptake, discuss the use of tracers to measure DON uptake, and briefly review some of the more recent work on DON uptake in the field, particularly in reference to harmful algal bloom (HAB) species.

\subsection{Methods to measure phytoplankton and bacterial nitro- gen uptake rates}

Marine phytoplankton and heterotrophic bacteria are known to utilize similar pools of inorganic and organic $\mathrm{N}$ substrates, and this use of shared resources can result in a competitive interaction that could potentially control phytoplankton community composition. To distinguish between autotrophic and heterotrophic $\mathrm{N}$ uptake in an experiment, it is necessary to separate the two plankton groups. Each of the various methods that have been employed has its advantages and drawbacks. The most commonly utilized technique has been size fractionation, in which filters (in the size range of 0.7 to $1.2 \mu \mathrm{m})$ target the size differences between bacteria and phytoplankton (e.g. Wheeler and Kirchman, 1986; Kirchman et al., 1989; Mulholland et al., 2002; Rodrigues and Williams, 2002). The most commonly used filters in ${ }^{15} \mathrm{~N}$ studies are glass fiber filters (i.e. Whatman GF/F) because they are relatively inexpensive, can be precombusted to remove $\mathrm{N}$, and are compatible with mass spectrometric analysis. Size fractionation may be easier and more time-efficient than other approaches, but can lead to inaccurate estimates of $\mathrm{N}$ use by phytoplankton due to clogging effects and the size overlap between bacteria and phytoplankton. Studies from a range of marine ecosystems have shown that GF/F filters can retain as much as $93 \%$ (40 to $75 \%$ on average) of the bacterial community (Lee and Fuhrman, 1987; Lee et al., 1995; Gasol and Morán, 1999; Berg et al., 2001), yet ${ }^{15} \mathrm{~N}$ uptake measured on GF/F filters has traditionally been attributed to phytoplankton. Other researchers have attempted to avoid this methodological problem through the use of metabolic inhibitors such as streptomycin and cycloheximide, which block the function of ribosomes in prokaryotes and eukaryotes, respectively 
(Wheeler and Kirchman, 1986; Middelburg and Nieuwenhuize, 2000a and b; Veuger et al., 2004). However, this method can introduce artifacts to uptake rate measurements due to the lack of specificity and incomplete inhibition of these chemicals on target organisms (Oremland and Capone, 1988; Lee et al., 1992). Dark nutrient bioassays have also been used to a limited extent in field, mesocosm, and culture experiments to distinguish between phytoplankton and bacterial $\mathrm{N}$ uptake despite the fact that many phytoplankters are known to take up $\mathrm{N}$ in the dark (e.g. Gobler et al., 2002; Joint et al., 2002; Glibert et al., 2004). Finally, molecular approaches have recently gained popularity as a means of qualitatively describing the $\mathrm{N}$ utilization capabilities of marine phytoplankton and bacteria by measuring the activity of enzymes involved in $\mathrm{N}$ assimilation, such as nitrate reductase, urease, and aminopeptidase (Collier et al., 1999; Allen et al., 2001; Lopez-Lozano et al., 2002; Zehr and Ward, 2002; Dyhrman and Anderson, 2003; Fan et al., 2003b; Lomas, 2004). It is important to note, however, that the molecular techniques do not provide quantitative estimates of $\mathrm{N}$ uptake. Furthermore, none of the approaches described above can quantitatively distinguish between autotrophic and heterotrophic $\mathrm{N}$ uptake.

A promising newer approach is the use of flow cytometric sorting to physically separate phytoplankton from bacteria following tracer-addition experiments. Originally introduced into marine planktology to rapidly and precisely estimate the abundance of pico- and nanophytoplankton in marine food web studies (e.g. Olson et al., 1983, 1985; Yentsch et al., 1983; Chisholm et al., 1988), flow cytometry now has a wide variety of applications in aquatic microbial ecology (e.g. Wallner et al., 1997; Dubelaar and Jonker, 2000; Reckermann, 2000; Veldhuis and Kraay, 2000; Vives-Rego et al., 2000; Campbell, 2001; Collier, 2004), including routine analysis of the abundance of marine heterotrophic bacteria (e.g. Monger and Landry, 1993) and viruses (Marie et al., 1999). Using the sorting capability of a flow cytometer, researchers can isolate cells of interest based on unique optical properties conveyed by the presence of pigments, such as the red autofluorescence of chlorophyll. Following traditional ${ }^{15} \mathrm{~N}$ tracer incubations, chlorophyll-containing phytoplankton can be sorted and analyzed using a mass spectrometer to directly quantify phytoplankton $\mathrm{N}$ uptake. This approach to measuring $\mathrm{N}$ uptake was pioneered by Lipschultz (1995), who used flow cytometric sorting to measure uptake rates of ${ }^{15} \mathrm{~N}$-labeled $\mathrm{NH}_{4}^{+}$and $\mathrm{NO}_{3}^{-}$by coastal phytoplankton, consequently removing the effects of detritus and heterotrophs on uptake rate measurements. Similarly, Zubkov and Tarran (2005) used ${ }^{35}$ S-labeled methionine and cell sorting to estimate DFAA uptake in Prochlorococcus and Synechococcus sampled from oligotrophic surface waters of the South Atlantic. Others have employed flow cytometric sorting in a similar manner to measure the primary production of specific ultraphytoplankton groups $(\mathrm{Li}, 1994)$ and to examine the growth rates and ${ }^{13} \mathrm{C}$ isotopic signatures of fresh- water cyanobacteria and other algal taxa (Pel et al., 2004). One important consideration in using flow cytometric sorting to measure plankton activity is the effect of the sorting method on the health and integrity of individual cells. To this end, Rivkin et al. (1986) examined the incorporation of radioactively-labeled compounds into phytoplankton cells both before and after sorting, and found that sorting did not affect cellular radioactivity when performed after incubations, but did in fact lead to diminished primary production estimates when cells were sorted prior to incubation. Thus, flow cytometric sorting of autotrophic cells represents a feasible approach to measure rates of phytoplankton-specific $\mathrm{N}$ uptake.

A recent study, in an estuarine system, illustrates the importance of separating phytoplankton from bacteria. The influence of bacteria on $\mathrm{N}$ uptake rates was examined in surface water samples collected along the main axis of Chesapeake Bay during late summer. Uptake rates were measured in the traditional GF/F fraction as well as on autotrophic samples that had been sorted based on the presence of chlorophyll a. Results indicate that the inclusion of bacterial biomass on $\mathrm{GF} / \mathrm{F}$ filters resulted in overestimates of $\mathrm{NH}_{4}^{+}$, urea, and amino acid uptake rates of 69 to $125 \%$, when compared to phytoplankton-specific $\mathrm{N}$ uptake, and an underestimate of $58 \%$ for $\mathrm{NO}_{3}^{-}$uptake (Bradley and Bronk, 2007 ${ }^{1}$ ).

\subsection{Tracers for DON uptake}

Bioassays can also be used to quantify uptake rates of individual DON compounds but they are prone to the same problems encountered with bioassays that monitor the uptake of the bulk DON pool (see Sect. 2.2 above). To avoid these problems, substrates labeled with ${ }^{15} \mathrm{~N}$ can be used to measure uptake rates even in systems where uptake and regeneration are tightly coupled. Urea and amino acids are the most frequently studied DON forms because they have been commercially available in both single- $\left({ }^{15} \mathrm{~N}\right)$ and dual-labeled $\left({ }^{15} \mathrm{~N}\right.$ and ${ }^{13} \mathrm{C}$ ) forms; numerous individual amino acids can also be obtained as such. Other labeled organic tracers available include whole algal hydrosylate and lyophilized algal cells (i.e. combined amino acids), purines (e.g. guanine), pyrimidines (e.g. uracil), DNA nucleotides (e.g. guanosine monophosphate, adenosine triphosphate [ATP]), acetamide, and creatine. In addition, some researchers have examined the uptake of in situ produced ${ }^{15} \mathrm{~N}$-labeled DON derived from plankton cells grown on ${ }^{15} \mathrm{NH}_{4}^{+}$or ${ }^{15} \mathrm{NO}_{3}^{-}$(Bronk and Glibert, 1993; Veuger et al., 2004), from Trichodesmium using ${ }^{15} \mathrm{~N}_{2}$ gas (Bronk et al., 2004), or labeled humic material derived from Spartina alterniflora that was grown with ${ }^{15} \mathrm{~N}$-labeled $\mathrm{NH}_{4}^{+}$added to the sediment (See and Bronk, 2005; See et al., 2006).

\footnotetext{
${ }^{1}$ Bradley, P. and Bronk, D. A.: Phytoplankton and bacterial nitrogen uptake in Chesapeake Bay measured using a flow cytometry approach, submitted, 2007.
} 


\subsection{Phytoplankton versus bacterial uptake}

Traditionally the inorganic forms were thought to exclusively support primary production. Research over the past three decades, however, has shown not only that bacteria balance their DON consumption with uptake of inorganic nutrients (Wheeler and Kirchman, 1986; reviewed in Kirchman, 2000), but also that phytoplankton from various marine ecosystems use DON to meet their cellular $\mathrm{N}$ demands (reviewed in Antia et al., 1991; Bronk, 2002; Berman and Bronk, 2003). DON uptake by phytoplankton was reported as early as 1957 (Hattori, 1957), and examined further by McCarthy in the 1970s (McCarthy, 1972a, b); however, these early studies of phytoplankton DON use focused mainly on the metabolism and kinetics of urea uptake. In contrast to this early emphasis on urea uptake at the cellular to individual species level, research has more recently focused on the ecological implications at a community level (e.g. Lomas et al., 2002).

In general, phytoplankton prefer $\mathrm{NH}_{4}^{+}$over other $\mathrm{N}$ sources because this reduced form requires the least amount of energy to assimilate. Nonetheless, $\mathrm{NH}_{4}^{+}$is not always the dominant $\mathrm{N}$ substrate utilized by marine phytoplankton; DON uptake has been shown in some studies to satisfy a large portion of the autotrophic $\mathrm{N}$ requirement. For example, the contribution of urea and DFAA to total measured $\mathrm{N}$ uptake by coastal phytoplankton assemblages varies, but has been shown to reach as high as $80 \%$ (Harrison et al., 1985; Kristiansen, 1983; Glibert et al., 1991; Berg et al., 2001; Veuger et al., 2004). In addition, phytoplankton communities appear to rely more heavily on reduced $\mathrm{N}$, including DON, during summer months when ambient $\mathrm{NO}_{3}^{-}$concentrations are typically minimal (Paerl, 1991; Berg et al., 2003a). This apparent increase in autotrophic DON use during summer could also be the result of a high bacterial demand on available dissolved inorganic N (DIN), which has been demonstrated to suppress phytoplankton biomass (Joint et al., 2002) and may even exert a selective pressure on phytoplankton species capable of exploiting available organic substrates.

Attributing the uptake of different types of dissolved $\mathrm{N}$ to specific phytoplankton groups in the field has been difficult at best, however, some general trends have emerged. For example, large and/or rapid inputs of $\mathrm{NO}_{3}^{-}$are known to stimulate blooms of diatoms, which are physiologically suited to take advantage of and grow quickly with the onset of $\mathrm{NO}_{3}^{-}$-rich conditions (Goldman, 1993; Lomas and Glibert, 1999a). Berg et al. (2003a) used linear regression analysis to link the abundance of diatoms in the Gulf of Riga (Baltic Sea) with $\mathrm{NO}_{3}^{-}$uptake during spring; a negative correlation with DFAA uptake during the summer suggests that diatoms are not among the phytoplankton that exploit DON sources in this system. Dinoflagellates and cyanobacteria, on the other hand, are typically associated with increased availability of reduced $\mathrm{N}$, such as $\mathrm{NH}_{4}^{+}$and urea, relative to $\mathrm{NO}_{3}^{-}$(Berg et al., 1997; Lomas and Glibert, 1999b; Berg et al., 2003a). In comparison, heterotrophic bacteria tend to rely predominantly on DFAA and $\mathrm{NH}_{4}^{+}$(Keil and Kirchman, 1991; Kroer et al., 1994; Hoch and Kirchman, 1995; Middelburg and Nieuwenhuize, 2000a and b), although other studies have shown substantial bacterial uptake of $\mathrm{NO}_{3}^{-}$in various marine ecosystems (Kirchman et al., 1991; Kirchman and Wheeler, 1998; Allen et al., 2002). In general, urea is not considered important in bacterial nutrition (e.g. Cho et al., 1996; Tamminen and Irmisch, 1996) though a recent study has called that into question (Jørgensen, 2006).

This is another area where the combined flow cytometry stable isotope approach will be particularly useful. A highspeed flow cytometric sorter was used to demonstrate direct $\mathrm{NO}_{3}^{-}$uptake by Prochlorococcus in the deep chlorophyll maximum in the Sargasso Sea (Casey et al., 2007). This is consistent with the observation that Prochlorococcus often reaches its maximum abundance coincident with the nitracline. Measured rates of $\mathrm{NO}_{3}^{-}$uptake compare well with net Prochlorococcus population growth rates in the deep chlorophyll maximum and represent $5-10 \%$ of the total measured $\mathrm{N}$ uptake. This observation is contrary to growth studies with cultured isolates of Prochlorococcus (Moore et al., 2002), but consistent with the proposition that the dominant low-light Prochlorococcus ecotype is not presently in culture (Zinser et al., 2006; Ahlgren et al., 2005). Flow cytometric sorting was also used to quantify Aureococcus-specific uptake during a bloom in Chincoteague Bay, MD. Results indicate that A. anophagefferens and bacteria both took up $\mathrm{NH}_{4}^{+}, \mathrm{NO}_{3}^{-}$, urea, and leucine, but that uptake of organic compounds by $A$. anophagefferens far exceeded uptake by bacteria at all stages of the bloom and for all compounds (Boneillo and Mulholland, in preparation).

There are also some other powerful new tools that can be used in future research. For example, the information gained from the sequencing of phytoplankton, such as Synechococcus (Palenik et al., 2003), Prochlorococcus (Dufresne et al., 2003; Rocap et al., 2003), and a diatom (Armbrust et al., 2004), can be used to inform field research by highlighting which substrates are likely to be used by certain groups based on the presence or absence of transporters. This information could then be used to target which phytoplankton populations to target using flow cytometry for certain substrates. The combination of molecular tools with classic biogeochemical tracers also holds much potential for defining which groups may be active in the uptake of a given compound. For example, Cottrell and Kirchman (2000) used microautoradiography and fluorescence in situ hybridization (MICRO FISH) to investigate which bacterial groups dominate uptake of a number of compounds including proteins and amino acids. Another approach is to use stable isotope probing (Radajewski et al., 2000). With this technique a substrate labeled with ${ }^{15} \mathrm{~N}$ or ${ }^{13} \mathrm{C}$ is added to a water sample and then the incorporation of the label is followed into DNA. The "heavy" DNA that has ${ }^{15} \mathrm{~N}$ or ${ }^{13} \mathrm{C}$ incorporated in it is separated from the other DNA using density gradient cell centrifugation. Gene 
probing and sequence analysis can then be used to characterize the labeled DNA to determine which taxonomic or functional group of organisms utilized the substrate (e.g. Gallagher et al., 2005).

\subsection{The special case of HABs}

With increased evidence that some DON is labile, it has been suggested that specific DON components could exert selective pressure over phytoplankton community composition (Paerl, 1997; Seitzinger and Sanders, 1997; Berman and Chava, 1999). Phytoplankton species capable of utilizing DON may have a competitive advantage in organically enriched environments where the DIN supply is limited. In particular, it appears that some harmful algae species are capable of using DON for nutrition and may prefer it to inorganic sources (e.g. Lomas et al., 1996; Berg et al., 1997; Herndon and Cochlan, 2007). Specifically, dinoflagellates seem to have an affinity for organic N (Palenik and Morel, 1990a, 1991; Glibert and Terlizzi, 1999; Dyhrman and Anderson, 2003; Fan et al., 2003a). A high affinity for urea by the dinoflagellate Prorocentrum minimum contributed significantly to a bloom in the Neuse River estuary (Fan et al., 2003a) and ambient urea concentrations were found to provide a potentially large proportion of the $\mathrm{N}$ required by the red tide alga, Lingulodinium polyedrum (Kudela and Cochlan, 2000). Other classes of phytoplankton besides dinoflagellates have also been shown to utilize DON. One example is the case of Aureococcus anophagefferens, an organism known to produce severe brown tides off the coast of Long Island, NY. Natural and added inputs of DON, particularly urea, stimulate its growth (Gobler and SañudoWilhelmy, 2001) and in one study approximately $70 \%$ of the total $\mathrm{N}$ utilized during an $A$. anophagefferens bloom event was identified as organic N (Berg et al., 1997). A study with the toxigenic diatom Pseudo-nitzschia australis found that the exponential growth rate of cells grown on urea was significantly lower than those grown on $\mathrm{NH}_{4}^{+}$or $\mathrm{NO}_{3}^{-}$but that cells using urea had a domoic acid production rate two times higher than cells using $\mathrm{NO}_{3}^{-}$and three times higher than cells using $\mathrm{NH}_{4}^{+}$(Howard et al., 2007).

Bronk et al. (2004) quantified the ability of the red tide former, Karenia brevis, to utilize ${ }^{15} \mathrm{~N}$-labeled inorganic $\left(\mathrm{NH}_{4}^{+}\right.$, $\mathrm{NO}_{3}^{-}$) as well as organic substrates (urea and glutamate) during kinetics experiments and demonstrated that although all the substrates could be utilized, the uptake of organic substrates did not exhibit the classic hyperbolic MichaelisMenten kinetic curves. The lowest substrate additions $(0.055,0.01 \mu \mathrm{M})$ resulted in high specific uptake rates. This was followed by an abrupt decrease in specific uptake rates as the substrate concentrations increased - the opposite trend of what would be expected for uptake following the MichaelisMenten model. Similar kinetic curves were also observed during amino acid uptake by A. anophagefferens (Mulholland et al., 2002). A similar situation was observed in an earlier study in which urea uptake rates at the lowest concentrations were relatively high; those results were attributed to error in the determination of ambient nutrient concentrations, which were approaching the limit of detection (Eppley et al., 1977). In the K. brevis study, however, ambient concentrations were fairly high such that substantial analytical error is unlikely. Another possibility is that the range of atom $\%$ enrichments that produced the elevated urea and glutamate rates were lower than the atom $\%$ enrichments used in the inorganic uptake, which would contribute to the elevated rates at low concentrations. However, the atom \% enrichment range for the organics used in the $K$. brevis study were within the range of substrate enrichments used in numerous other studies where no increase in uptake at low concentrations has been observed. Furthermore, uptake experiments have been performed where the concentration of the substrate was held constant and the atom $\%$ enrichment was varied down to 0.01 atom \% with no increase in uptake (Mulholland and Capone, unpubl. data). Another theory is that the increased rates at low concentrations are the result of a bimodal uptake mechanism. More research is necessary to define the mechanisms behind the observed deviation from Michaelis-Menten kinetics, and whether this phenomenon is restricted to HAB species.

\subsection{Why should we care where the DON goes?}

Although research on DIN and DON uptake by phytoplankton and bacteria has been fairly extensive, relatively little is known about how these two groups compete for limiting $\mathrm{N}$ resources and how this interaction affects the community composition in the environment. Such interactions are driven primarily by the absolute and relative availability of different $\mathrm{N}$ substrates in the euphotic zone, but the extent to which other factors such as light and temperature, as well as biological and physical processes, affect the outcome of this interaction remains a key area for future research. Furthermore, the relevant temporal and spatial scales at which this question is addressed will have implications with respect to the significance of phytoplankton versus bacterial $\mathrm{N}$ use.

In estuarine and coastal ecosystems, the relative use of organic $\mathrm{N}$ by autotrophs and heterotrophs will potentially affect plankton community composition, energy transfer to higher trophic levels, benthic-pelagic coupling, and the stimulation of HABs. As discussed above, specific types of $\mathrm{N}$ tend to favor dominance by particular phytoplankton groups, which will affect how primary production is transferred to higher trophic levels. For example, inputs of $\mathrm{NO}_{3}^{-}$into a $\mathrm{N}$-limited coastal system tend to promote diatom blooms, which are either consumed by grazers or sink out of the water column promoting benthic-pelagic coupling. On the other hand, cyanobacteria and dinoflagellates appear to prefer reduced $\mathrm{N}$ substrates such as $\mathrm{NH}_{4}^{+}$, urea, and DFAA; members of these phytoplankton groups (especially toxic species) are commonly considered to be nutritionally inferior to grazers, 
relative to diatoms, and thus represent a diminished supply of energy to upper trophic levels. Finally, the ability of bacteria to capitalize on available DIN during N-limited conditions may intensify cycling within the microbial loop and disconnect surface production from benthic micro- and macrofauna. Clearly, the type of $\mathrm{N}$ entering coastal and estuarine waters can play a significant role in altering plankton community structure, but may also affect broader scale processes determining overall ecosystem health.

In oceanic systems, the fate of $\mathrm{N}$ into phytoplankton versus bacterial biomass has significant implications with respect to $\mathrm{N}$ and $\mathrm{C}$ cycling on both ecosystem and global scales. New production, which is defined as primary production derived from "new" or allochthonous sources of $\mathrm{N}$, has been used to quantify the energy available to support higher trophic levels (Dugdale and Goering, 1967). The $f$-ratio, which is the ratio of new to total (new plus regenerated) production (Eppley and Peterson, 1979), has traditionally been calculated by dividing ${ }^{15} \mathrm{NO}_{3}^{-}$uptake (i.e. new production) by the summed uptake of ${ }^{15} \mathrm{NH}_{4}^{+}$(i.e. regenerated production) and ${ }^{15} \mathrm{NO}_{3}^{-}$(e.g. Harrison et al., 1987). However, this method does not reflect the various organic compounds potentially utilized by phytoplankton. The inclusion of bacterial uptake in ${ }^{15} \mathrm{~N}$ uptake rates assumed to represent phytoplankton production can also be problematic (Kirchman et al., 1992). The recent results from flow cytometric stable isotope studies described above indicates that inclusion of bacterial biomass in ${ }^{15} \mathrm{~N}$ uptake rates can result in both under- or overestimates in uptake rates (discussed above, Bradley and Bronk, 2007 ${ }^{1}$ ) resulting in dramatically different $f$-ratios. Use of such biased estimates of new production in models of the global $\mathrm{C}$ cycle, for example, could therefore overstate the potential drawdown of anthropogenic $\mathrm{C}$ dioxide by the oceans.

\section{Mechanisms for accessing DON}

With the accumulation of evidence that indicates phytoplankton use DON, additional effort has been directed at defining the likely mechanisms used to access this large but heterogeneous pool. Here we review data on enzymatic breakdown, pino- and phagocytosis, and photochemical decomposition.

\subsection{Enzymatic breakdown}

Forms of DON are made available to phytoplankton via a number of mechanisms. For smaller molecules, such as urea and some amino acids, uptake can occur by active transport driven by a sodium ion pump or through facilitated diffusion if the concentrations outside the cell are high enough concentrations $(\mathrm{mM})$ to create a concentration gradient, something unlikely in the field (reviewed in Mulholland and Lomas, 2007). For larger compounds ( $>1 \mathrm{kDa})$ such as proteins, polypeptides, and humic acids, direct uptake through the use of transport proteins cannot occur and phytoplankton must find other mechanisms of accessing the nutrients such as the use of proteolytic enzymes (reviewed in Lewitus, 2005 and Berges and Mulholland, 2007). These enzymes are able to break down large polymers into their smaller constituent molecules, which can then be taken up by the cell. Proteolytic enzymes can be found intracellularly, attached to the outside of the cell or can be released from the cell into the surrounding media; the latter two are termed extracellular enzymes (Chróst, 1991). Traditionally, it has been thought that proteolytic enzyme activity was strictly a characteristic of heterotrophic bacteria (e.g. Sinsabaugh et al., 1997). However, recent studies have shown that phytoplankton can utilize these mechanisms of nutrient acquisition, with the two primary types of proteolytic enzyme activities believed to be amino acid oxidation and peptide hydroysis (Mulholland et al., 2003).

Amino acid oxidases are enzymes that cleave off free amino acids and primary amines to produce extracellular $\mathrm{H}_{2} \mathrm{O}_{2}, \mathrm{NH}_{4}^{+}$, and $\alpha$-keto acids or aldehydes; the free $\mathrm{NH}_{4}^{+}$is then taken up by the cell (Palenik and Morel, 1991). This pathway has been quantified using the fluorescently-labeled amino acid, LYA-lysine (Pantoja and Lee, 1994; Mulholland et al., 1998). One study found that three different species of phytoplankton possessed cell-surface L-amino acid oxidases that produced $\mathrm{NH}_{4}^{+}$, which was subsequently taken up and used for growth (Palenik and Morel, 1991). Several other species of phytoplankton are also known to possess amino acid oxidases (Palenik and Morel, 1991; Mulholland et al., 2003) and this process occurs across a range of systems (Mulholland et al., 1998). One estimate is that 20\% of the DON utilization in coastal and oceanic environments may be due to phytoplankton utilization of amino acid oxidases (Mulholland et al., 1998).

Peptide hydrolysis is another proteolytic process in bacteria and phytoplankton whereby the peptide bonds of proteins and polypeptides are broken, liberating smaller peptides and amino acids. A study by Mulholland et al. (2002) found high rates of peptide hydrolysis in non-axenic cultures of Aureococcus anophagefferens. Leucine aminopeptidase (LAP) is one class of proteolytic enzyme capable of hydrolyzing peptide bonds. LAP is capable of breaking down a number of substrates, but has a preference for the terminal $\mathrm{N}$ of non-polar amino acids such as leucine (Langheinrich, 1995). Even if phytoplankton are incapable of producing their own extracellular enzymes, they may still benefit from those released by bacteria or by liberation of bacterial intracellular enzymes. Proteolytic enzymes may be freed from bacteria by cell lysis or released due to grazing on bacteria (Chrst, 1991), and there is some evidence that phytoplankton, in association with bacteria, may be able to utilize monomers derived from bacterial enzymatic activity. For example, high aminopeptidase activity (10 to $90 \%$ of activity) has been found in $0.2 \mu \mathrm{m}$ filtrates (Jacobsen and Rai, 1991), indicating that enzymes had been liberated from bacteria. These enzymes could still have the capability to break off free amino 
acids that could subsequently be used for uptake by other organisms.

In a more general sense, the use of cell-surface enzymes capable of cleaving amino groups is also a potential mechanism used to access the approximately $50 \%$ of humic- $\mathrm{N}$ that is in the form of amino acids, amino sugars, $\mathrm{NH}_{4}^{+}$, and nucleic acid bases (Schnitzer, 1985). It is likely that these enzymes are capable of cleaving the $\mathrm{N}$ from a wide range of additional DON compounds allowing phytoplankton to, in effect, "farm" $\mathrm{N}$ from these compounds while leaving the remainder of the compound external to the cell (Mulholland et al., 1998; Berg et al., 2003b; Stoecker and Gustafson, 2003).

\subsection{Pinocytosis and phagocytosis}

DON can also be taken up by some phytoplankton by two similar processes - pinocytosis and phagocytosis. Pinocytosis is a process where the cells ingest dissolved macromolecules from the medium outside the cell. Phagocytosis is an engulfing of particulate material from outside the cell. Cells undergoing pinocytosis expand a vesicle from the plasma membrane to engulf molecules and pull them inside the cell, where they can be accumulated inside a vacuole. Prior studies with dinoflagellates, euglenoids, and chlorophytes have found pinocytosis to be a common method for ingesting dissolved macromolecules (Kivic and Vest, 1974; Klut et al., 1987). In one case, the HAB-forming dinoflagellate, Alexandrium catenella, directly took up fluorescently labeled dextran (Legrand and Carlsson, 1998). The use of similar markers, such as lectins and peroxidases, has also demonstrated pinocytosis in the flagellates Amphidinium carterae and Prorocentrum micans (Klut et al., 1987). Phagocytosis by marine and freshwater phytoflagellates is well documented (e.g. Sanders and Porter, 1988) and occurs under a wide range of light and nutrient regimes. In phytoplankton, phagotrophy is also seen in the photosynthetic bloomforming dinoflagellates Heterocapsa triquetra and Ceratium furca (Legrand et al., 1998; Smalley et al., 1999). Supplementing their nutrition in this manner could give some phytoplankton a competitive advantage over other strictly photoautotrophic organisms and would allow nutrient acquisition even during unfavorable conditions ( $\mathrm{Li}$ et al., 2000a and b). The ability to utilize additional modes of nutrient acquisition could make one species more successful than another, leading to bloom formation (e.g. Smayda, 1997; Stoecker et al., 1997; Jeong et al., 2005a and b). As a result pino- and phagocytosis are of particular interest to researchers studying HABs.

Furthermore, pinocytosis and phagocytosis are two processes that could potentially be used to access $\mathrm{N}$ associated with large organic compounds, such as humics. Experiments have been conducted using dual-labeled humic substances $\left({ }^{15} \mathrm{~N},{ }^{13} \mathrm{C}\right)$ based on the assumption that if pino- or phagocytosis were used to take up the humics, both ${ }^{15} \mathrm{~N}$ and ${ }^{13} \mathrm{C}$ would be taken up in the same stoichiometric ratio as they appear in the labeled humics. In experiments with three coastal phytoplankton strains known to take up humic-N, Synechococcus sp., Amphidinium carterae, and Thalassiosira cf. miniscula, no uptake of ${ }^{13} \mathrm{C}$ was measured indicating that the humics were not taken up whole using these mechanisms (See et al., 2006).

\subsection{Photochemical decomposition}

An alternative method for the acquisition of $\mathrm{N}$ from humic substances is photooxidation followed by uptake of the $\mathrm{N}$ photoproducts. Due to their aromatic nature, humic substances are particularly photoreactive to ultraviolet (UV) light and release inorganic N (Bushaw et al., 1996; Bushaw-Newton and Moran, 1999; Kieber, 2000) and small labile organic molecules (e.g. amino acids and urea) into the surrounding environment when exposed to UV radiation (Amador et al., 1989; Jørgensen et al., 1998; BushawNewton and Moran, 1999; Koopmans and Bronk, 2002). Of these compounds, $\mathrm{NH}_{4}^{+}$generally has the greatest observed rates of production (Bushaw et al., 1996; Gao and Zepp, 1998). Photochemical release has been observed in a number of locations including an estuary in Georgia (Bushaw et al., 1996; Gao and Zepp, 1998) and a humic-rich lake in Venezuela (Gardner et al, 1998). Photodegradation of DOM increases the availability of more labile $\mathrm{N}$ sources to phytoplankton and bacteria.

\subsection{Possible humic shuttle}

In addition to the direct utilization of DON compounds, it is possible for some HMW compounds to act as a transport mechanism. Humic acids contain a high concentration of cation exchange sites, allowing them to retain and exchange numerous ions from the surrounding waters. For example, humic compounds in marine clay sediments can account for a large percentage of the cation exchange capabilities of the marine benthic environment (Rashid, 1969). Additional studies show that $\mathrm{NH}_{4}^{+}$can be adsorbed to humics in the estuarine and nearshore environment (Rosenfeld, 1979; Gardner et al., 1991). This $\mathrm{NH}_{4}^{+}$can then be released into the surrounding water column as the cation exchange sites on the humic compound are exposed to increased salt concentrations (Rosenfeld, 1979; Gardner et al., 1991 and 1998; See, 2003; See and Bronk, 2005).

In coastal systems, humic and $\mathrm{NH}_{4}^{+}$concentrations are often high in the low salinity upland river marshes. In these locations, $\mathrm{NH}_{4}^{+}$can be adsorbed on the cation binding sites found on the humic structure. As humic compounds are flushed downriver and interact with more saline waters the adsorbed $\mathrm{NH}_{4}^{+}$can be replaced with salt ions on the humic structure, thereby making the newly released inorganic $\mathrm{N}$ directly available to phytoplankton and bacteria for uptake. Studies of aquatic humics collected from three U.S. east coast rivers (York, Altamaha, and Satilla) confirmed the 
Table 1. Labile, semi-labile and refractory components of the DON pool.

\begin{tabular}{lll}
\hline Labile & Semi-labile & Refractory \\
\hline Urea & Proteins & Humic acids \\
DFAA & DCAA & Fulvic acids \\
Nucleic acids & Amino polysaccharides & Porphorins \\
Methylamines & (e.g. chitins and peptidoglycans) & Amides \\
\hline
\end{tabular}

ability of humic material to adsorb and subsequently release $\mathrm{NH}_{4}^{+}$to the environment along an estuarine salinity gradient, thus acting as a "shuttle" delivering labile $\mathrm{N}$ to more $\mathrm{N}$ limited mesohaline regions of the estuary and coastal ocean (See, 2003; See and Bronk, 2005). Preliminary results indicate that this "humic shuttle" is capable of releasing approximately $1 \mu \mathrm{mol}$ of $\mathrm{N}$ per liter of water passing through the estuary over the course of a year $\left(\sim 77 \times 10^{6} \mathrm{~g}\right.$ of $\mathrm{N}$ into the Altamaha estuary) and is a previously unrecognized source of $\mathrm{N}$ to the mesohaline estuary and coastal ocean (Beck et al., 1974; Alberts and Takács, 1999).

\section{Conclusions}

In the past DON was viewed as a large refractory pool that only contributed to bacterial production over relatively long time scales. Today the DON pool is more accurately envisioned as being composed of at least two distinct pools - a large refractory pool, which likely turns over on timescales of months to years, and the "doughnut" fraction composed of highly labile compounds, such as amino acids and urea, that likely turns over in minutes to days. This labile fraction has been shown to contribute to autotrophic production, in addition to the more traditionally viewed bacterial fraction. Recent findings on DON utilization argue strongly for inclusion of DON in $\mathrm{N}$ loading budgets to coastal zones and estuaries, particularly as they may contribute to growth of the primary producers.

Acknowledgements. The authors wish to thank H. Paerl and an anonymous reviewer for thorough, thought-provoking reviews - the manuscript benefited immensely. The writing of this manuscript was supported by NSF grant OCE-02218252 to DAB. This is contribution number 2760 of the Virginia Institute of Marine Science, The College of William and Mary.

Edited by: S. W. A. Naqvi

\section{References}

Ahlgren, N. A., Rocap, G., and Chisholm, S. W.: Measurement of Prochlorococcus ecotypes using real-time polymerase chain reaction reveals different abundances of genotypes with similar light physiologies, Environ. Microbiol., 8, 441-454, 2005.

Aiken, G. R.: A critical evaluation of the use of macroporous resins for the isolation of aquatic humic substances, John Wiley and Sons, New York, 1988.

Alberts, J. J. and Takács, M.: Importance of humic substances for carbon and nitrogen transport into southeastern United States estuaries, Organ. Geochem., 30, 385-395, 1999.

Algeus, S.: The deamination of glycocoll by green algae, Physiologia Plantarum, 1, 343-409, 1948.

Allen, A. E., Booth, M. G., Frischer, M. E., Verity, P. G., Zeh,r J. P., and Zani, S.: Diversity and detection of nitrate assimilation genes in marine bacteria, Appl. Environ. Microbiol., 67, 53435348, 2001.

Allen, A. E., Howard-Jones, M. H., Booth, M. G., Frischer, M. E., Verity, P. G., Bronk, D. A., and Sanderson M. P.: Importance of heterotrophic bacterial assimilation of ammonium and nitrate in the Barents Sea during summer, J. Mar. Syst., 38, 93-108, 2002.

Aluwihare, L., Repeta, D., and Chen, R.: A major biopolymeric component to dissolved organic carbon in surface seawater, Nature, 387, 166-169, 1997.

Aluwihare, L. I., Repeta, D. J., Pantoja, S., and Johnson, C. G.: Two chemically distinct pools of organic nitrogen accumulate in the ocean, Science, 308(5724), 1007-1010, 2005.

Amador, J. A., Alexander, M., and Zika, R. G.: Sequential photochemical and microbial degradation of organic molecules bound to humic acid, Appl. Environ. Microbiol., 55, 2843-2849, 1989.

Antia, N. J., Harrison, P. J., and Oliveira, L.: Phycological Reviews 2: The role of dissolved organic nitrogen in phytoplankton nutrition, cell biology and ecology, Phycologia, 30, 1-89, 1991.

Armbrust, E. V., Berges, J. A., Bowler, C., Green, B. R., Martinez, D., Putnam, N. H., Zhou, S., Allen, A. E., Apt, K. E., Bechner, M., Brzezinski, M., Chaal, B. K., Chiovitti, A., Davis, A. K., Demarest, M. S., Detter, J. C., Glavina ,A. K., Goodstein, D., Had, M. Z., et al.: The genome of the diatom Thalassiosira pseudonana: Ecology, evolution, and metabolism, Science, 306, 79-86, 2004.

Beck, G. M., Reuter, J. H., and Perdue, E. M.: Organic and inorganic geochemistry of some coastal plain rivers of the southeastern United States, Geochim. Cosmochim. Acta, 38, 341-364, 1974.

Benner, R.: Chemical composition and reactivity, in: Biogeochemistry of Marine Dissolved Organic Matter, edited by: Hansell, D. A. and Carlson, C. A., Academic Press, San Diego, pp. 59-90, 2002.

Benner, R., Pakulski, J. D., McCarthy, M., Hedges, J. I., and Hatcher, P. G.: Bulk chemical characteristics of dissolved organic matter in the ocean, Science, 255, 1561-1564, 1992.

Berg, G. M., Glibert, P. M., Lomas, M. W., and Burford, M. A.: Organic nitrogen uptake and growth by the chrysophyte Aureococcus anophagefferens during a brown tide event, Mar. Biol., 129, 377-387, 1997.

Berg, G. M., Glibert, P. M., Jørgensen, N. O. G., Balode, M., and Purina, I.: Variability in inorganic and organic nitrogen uptake associated with riverine nutrient input in the Gulf of Riga, Baltic Sea, Estuaries, 24, 204-214, 2001. 
Berg, G. M., Balode, M., Purina, I., Bekere, S., Béchemin, C., and Maestrini, S. Y.: Plankton community composition in relation to availability and uptake of oxidized and reduced nitrogen, Aquat. Microb. Ecol., 30, 263-274, 2003a.

Berg, G. M., Repeta, D. J., and La Roche, J.: The role of the picoeukaryote Aureococcus anophagefferens in cycling of marine high-molecular weight dissolved organic nitrogen, Limnol. Oceanog., 48, 1825-1830, 2003 b.

Berges, J. and Mulholland, M.: Enzymes and cellular N cycling, in: Nitrogen in the Marine Environment, edited by: Capone, D. G., Bronk, D. A., Mulholland, M., and Carpenter, E. J., Elsevier, San Diego, in press, 2008.

Berman, T. and Chava, S.: Algal growth on organic compounds as nitrogen sources, J. Plankton Res., 21, 1423-1437, 1999.

Berman, T. and Bronk, D. A.: Dissolved organic nitrogen: A dynamic participant in aquatic ecosystems, Aquat. Microb. Ecol., 31, 279-305, 2003.

Bronk D. A.: Dynamics of DON, in: Biogeochemistry of Marine Dissolved Organic Matter, edited by: Hansell, D. A. and Carlson, C. A., Academic Press, San Diego, pp. 153-249, 2002.

Bronk, D. and Glibert, P.: Application of a $15 \mathrm{~N}$ tracer method to the study of dissolved organic nitrogen uptake during spring and summer in Chesapeake Bay, Mar. Biol., 115, 501-508, 1993.

Bronk, D. A. and Ward, B. B.: Inorganic and organic nitrogen cycling in the Southern California Bight, Deep Sea Res. I., 52, 2285-2300, 2005.

Bronk, D. A., Glibert, P. M., Malone, T. C., Banahan, S., and Sahlsten, E.: Inorganic and organic nitrogen cycling in Chesapeake Bay: autotrophic versus heterotrophic processes and relationships to carbon flux, Aquat. Microb. Ecol., 15, 177-189, 1998.

Bronk, D. A., Sanderson, M. P., Mulholland, M. R., Heil, C. A., and O'Neil, J. M.: Organic and inorganic nitrogen uptake kinetics in field populations dominated by Karenia brevis, in: Harmful Algae 2002, edited by: Steidinger, K., Vargo, G. A., and Heil, C. A., Florida Fish and Wildlife Conservation Commission, Florida Institute of Oceanography and Intergovernmental Oceanographic Commission of UNESCO, St. Petersburg, FL, pp. 80-82, 2004.

Bushaw-Newton, K. L. and Moran, M. A.: Photochemical formation of biologically available nitrogen from dissolved humic substances in coastal marine systems, Aquat. Microb. Ecol., 18, 285-292, 1999.

Bushaw, K. L., Zepp, R. G., Tarr, M. A., Schulz-Jander, D., Bourbonniere, R. A., Hodson, R., Miller, W. L., Bronk, D. A., and Moran, M. A.: Photochemical release of biologically labile nitrogen from dissolved organic matter, Nature, 381, 404-407, 1996.

Campbell, L.: Flow cytometric analysis of autotrophic picoplankton, in: Marine Microbiology, edited by: Paul, J. H., Academic Press, San Diego, pp. 317-343, 2001.

Carlson, C. A. and Ducklow, H. W.: Dissolved organic carbon in the upper ocean of the central equatorial Pacific Ocean, 1992: Daily and fine scale vertical variations, Deep-Sea Res. II, 42, 639-656, 1995.

Carlsson, P. and Granéli, E.: Availability of humic bound nitrogen for coastal phytoplankton, Est. Coast. Shelf Sci., 36, 433-447, 1993.

Carlsson, P., Granéli, E., Tester, P., and Boni, L.: Influences of riverine humic substances on bacteria, protozoa, phytoplankton, and copepods in a coastal plankton community, Mar. Ecol. Prog. Ser.,
127, 213-221, 1995.

Carlsson, P., Edling, H., and Bechemin, C.: Interactions between a marine dinoflagellate (Alexandrium catenella) and a bacterial community utilizing riverine humic substances, Aquat. Microb. Ecol., 16, 65-80, 1998.

Carlsson, P., Granéli, E., and Segatto, A. Z.: Cycling of biologically available nitrogen in riverine humic substances between marine bacteria, a heterotrophic nanoflagellate and a photosynthetic dinoflagellate, Aquat. Microb. Ecol., 18, 23-36, 1999.

Casey, J., Lomas, M. W., Mandecki, J., and Walker, D.: Prochlorococcus contributes to new production in the Sargasso Sea deep chlorophyll maximum, Geophys. Res. Lett., in press, 2007.

Chisholm, S. W., Olson, R. J., Zettler, E. R., Goerick, R., Waterbury, J. B., and Welschmeyer, N. A.: A novel free-living prochlorophyte abundant in the oceanic euphotic zone, Nature, 334, 340343, 1988.

Cho, B., Park, M., Shim, J., and Azam, F.: Significance of bacteria in urea dynamics in coastal surface waters, Mar. Ecol. Prog. Ser., 142, 19-26, 1996.

Chróst, R. J.: Environmental control of the synthesis and activity of aquatic microbial ectoenzymes, in: Microbial Enzymes in Aquatic Environments edited by: Chróst, R. J., Springer, New York, pp. 25-59, 1991.

Church, M. J., Ducklow, H. W.. and Karl, D. M.: Multiyear increases in dissolved organic matter inventories at Station ALOHA in the North Pacific Subtropical Gyre, Limnol. Oceanogr., 47(1), 1-10, 2002.

Collier, J. L.: Flow cytometry and the single compound in plankton ecology, J. Phycol., 40, 805-807, 2004.

Collier, J. L., Brahamsha, B., and Palenik, B.: The marine cyanobacterium Synechococcus sp. WH7805 requires urease (urea amidohydrolase, EC 3.5.1.5) to utilize urea as a nitrogen source: molecular-genetic and biochemical analysis of the enzyme, Microbiol.-Sgm., 145, 447-459, 1999.

Cottrell, M. and Kirchman, D. L.: Natural assemblages of marine proteobacteria and members of the Cytophaga-Flavobacter cluster consuming low-and high-molecular-weight dissolved organic matter, Appl. Environ. Microb., 66(4), 1692-1697, 2000.

Doblin, M., Legrand, C., Carlsson, P., Hummert, C., Granéli, E., and Hallegraeff, G.: Uptake Of Humic Substances By the Toxic Dinoflagellate Alexandrium cantenella, in: Harmful Algal Blooms, edited by: Hallegraeff, G., Blackburn, S. I., Bolch, C. J., and Lewis, R. J., Intergovernmental Oceanographic Commission of Unesco, Paris, pp. 336-339, 2000.

Dubelaar, G. B. J. and Jonker, R. R.: Flow cytometry as a tool for the study of phytoplankton, Scientia Marina, 64, 135-156, 2000.

Dufresne, A., Salanoubat, M., Partensky, F., Artiguenave, F., Axmann, I. M., Galperin, M. Y., Koonin, E. V., Le Gall, F., Makarova, K. S., Ostrowski, M., Robert, C., Rogozin, I. B., Scanlan, D. J., Tandeau de Marsac, N., Weissenbach, J., Wincker, P., Wolf, Y. I., and Hess, W. R.: Genome sequencing of the cyanobacterium Prochlorococcus marinus SS120, a nearly minimal oxyphototrophic genome, Proc. Nat. Acad. Sci., 100, 10 020-10 025, 2003.

Dugdale, R. C. and Goering, J. J.: Uptake of new and regenerated forms of nitrogen in primary productivity, Limnol. Oceanog., 12, 196-206, 1967.

Dyhrman, S. T. and Anderson, D. M.: Urease activity in cultures and field populations of the toxic dinoflagellate, Alexandrium, 
Limnol. Oceanogr., 48, 647-655, 2003.

Eppley, R. W., Sharp, J. H., Renger, E. H., Perry, M. J., and Harrison, W. G.: Nitrogen assimilation by phytoplankton and other microorganisms in the surface waters of the central north Pacific Ocean, Mar. Biol., 39, 111-120, 1977.

Eppley, R. W. and Peterson, B. J.: Particulate organic matter flux and planktonic new production in the deep ocean, Nature, 282, 677-680, 1979.

Fan, C., Glibert, P., and Burkholder, J.: Characterization of the affinity for nitrogen, uptake kinetics, and environmental relationships for Prorocentrum minimum in natural blooms and laboratory cultures, Harmful Algae, 2, 283-299, 2003 a.

Fan, C., Glibert, P. M., Alexander, J., and Lomas, M. W.: Characterization of urease activity in three marine phytoplankton species, Aureococcus anophagefferens, Prorocentrum minimum, and Thalassiosira weissflogii, Mar. Biol., 142, 949-958, 2003b.

Fuhrman, J.: Close coupling between release and uptake of dissolved free amino acids in seawater studied by an isotope dilution approach, Mar. Ecol. Prog. Ser., 37, 45-52, 1987.

Gagnon, R., Levasseur, M., Weise, A. M., and Fauchot, J.: Growth stimulation of Alexandrium tamarense (Dinophyceae) by humic substances from the Manicouagan River (eastern Canada), J. Phycol., 41, 489-497, 2005.

Gallagher, E., McGuinness, L., Phelps, C., Young, L. Y., and Kerkhof, L. J.: ${ }^{13}$ C-Carrier DNA shortens the incubation time needed to detect benzoate-utilizing denitrifying bacteria by stable-isotope probing, Appl. Environ. Microb., 71(9), 51925196, 2005.

Gao, H. and Zepp, R. G.: Factors influencing photoreactions of dissolved organic matter in a coastal river of the Southeastern United States, Environ. Sci. Technol., 32, 2940-2946, 1998.

Gardner, W. S., Seitzinger, S. P., and Malczyk, J. M.: The effects of sea salts on the forms of nitrogen released from estuarine and freshwater sediments: Does ion pairing affect ammonium flux?, Estuaries, 14, 157-166, 1991.

Gardner, W. S., Cavaletto, J. F., Bootsma, H. A., Lavrentyev, P. J., and Tanvone, F.: Nitrogen cycling rates and light effects in tropical Lake Maracaibo, Venezuela, Limnol. Oceanogr., 43, 18141825, 1998.

Gasol, J. M. and Morán, X. A. G.: Effects of filtration on bacterial activity and picoplankton community structure as assessed by flow cytometry, Aquat. Microb. Ecol., 16, 251-264, 1999.

Glibert, P. M. and Terlizzi, D. E.: Cooccurrence of elevated urea levels and dinoflagellate blooms in temperate estuarine aquaculture ponds, Appl. Environ. Microbiol., 65(12), 5594-5596. 1999.

Glibert, P. M., Garside, C., Fuhrman, J. A., and Roman, M. R.: Time-dependent coupling of inorganic and organic nitrogen uptake and regeneration in the plume of the Chesapeake Bay estuary and its regulation by large heterotrophs, Limnol. Oceanogr., 36, 895-909, 1991.

Glibert, P. M., Heil, C. A., Hollander, D., Revilla, M., Hoare, A., Alexander, J., and Morasko, S.: Evidence for dissolved organic nitrogen and phosphorus uptake during a cyanobacterial bloom in Florida Bay, Mar. Ecol. Prog. Ser., 280, 73-83, 2004.

Gobler, C. J. and Sañudo-Wilhelmy, S. A.: Effects of organic carbon, organic nitrogen, inorganic nutrients, and iron additions on the growth of phytoplankton and bacteria during a brown tide bloom, Mar. Ecol. Prog. Ser, 209, 19-34, 2001.

Gobler, C. J., Renaghan, M. J., and Buck, N. J.: Impacts of nu- trients and grazing mortality on the abundance of Aureococcus anophagefferens during a New York brown tide bloom, Limnol. Oceanogr., 47, 129-141, 2002.

Goldman, J. C.: Potential role of large oceanic diatoms in new primary production, Deep-Sea Res. I, 40, 159-168, 1993.

Hansell, D. A., Williams, P. M., and Ward, B. B.: Measurements of DOC and DON in the Southern California Bight using oxidation by high temperature combustion, Deep-Sea Res., 40(2), 219-234, 1993.

Harrison, W. G., Head, E. J. H., Conover, R. J., Longhurst, A. R., and Sameoto, D. D.: The distribution and metabolism of urea in the eastern Canadian Arctic, Deep-Sea Res. I, 32, 23-42, 1985.

Harrison, W. G., Platt, T., and Lewis, M. R.: f-Ratio and its relationship to ambient nitrate concentration in coastal waters, J. Plankton Res., 9, 235-248, 1987.

Hattori, A.: Studies on the metabolism of urea and other nitrogenous compounds in Chlorella ellipsoidea. I. Assimilation of urea and other nitrogenous compounds by nitrogen-starved cells, J. Biochem. (Tokyo), 44, 253-273, 1957.

Hedges, J. I. and Hare, P. E.: Amino acid adsorption by clay minerals in distilled water, Geochim. Cosmochim. Acta., 51, 255-259, 1987.

Herndon, J. and Cochlan, W. P.: Nitrogen utilization by the raphidophyte Heterosigma akashiwo: Growth and uptake kinetics in laboratory cultures, Harmful Algae, 6, 260-270, 2007.

Hildebrand, M. and Dahlin, K.: Nitrate transporter genes from the diatom Cylindrotheca fusiformis (Bacillariophyceae): mRNA levels controlled by nitrogen source and by the cell cycle, J. Phycol., 36, 702-713, 2000.

Hildebrand, M.: Cloning and functional characterization of ammonium transporters from the marine diatom Cylindrotheca fusiformis (Bacillariophyceae), J. Phycol., 41, 105-115, 2005.

Hoch, M. P. and Kirchman, D. L.: Ammonium uptake by heterotrophic bacteria in the Delaware Estuary and adjacent coastal waters, Limnol. Oceanogr., 40, 886-897, 1995.

Howard, M. D. A., Cochlan, W. P., Ladizinsky, N., and Kudela, R. M.: Nitrogenous preference of toxigenic Pseudo-nitzschia australis (Bacillariophyceae) from field and laboratory experiments, Harmful Algae, 6, 206-217, 2007.

Jacobsen, T. and Rai, H.: Aminopeptidase activity in lakes of differing eutrophication, in: Microbial Enzymes in Aquatic Environments, edited by: Chróst, R., Springer-Verlag, New York, pp. 155-164, 1991.

Jeong, H. J., Yoo, Y. D., Park, J. Y., Song, J. Y., Kim, S. T., Lee, S. H., Kim, K. Y., and Yih, W. H.: Feeding by phototrophic redtide dinoflagellates: five species newly revealed and six species previously known to be mixotrophic, Aquat. Micro. Ecol., 40, 133-150, 2005a.

Jeong, H. J., Park, J. Y., Nho, J. H., Park, M. O., Ha, J. H., Seong, K. A., Jeng, C., Seong, C. N., Lee, K. Y., and Yih, W. H.: Feeding by red-tide dinoflagellates on the cyanobacterium Synechococcus, Aquat. Microb. Ecol., 41, 131-143, 2005 b.

Joint, I., Henriksen, P., Fonnes, G. A., Bourne, D., Thingstad, T. F., and Riemann, B.: Competition for inorganic nutrients between phytoplankton and bacterioplankton in nutrient manipulated mesocosms, Aquat. Microb. Ecol., 29, 145-159, 2002.

Jørgensen, N. O. G.: Uptake of urea by estuarine bacteria, Aquat. Microb. Ecol., 42, 227-242, 2006.

Jørgensen, N. O. G., Kroer, N., Coffin, R. B., Yang, X.-H., and Lee, 
C.: Dissolved free amino acids, combined amino acids, and DNA as sources of carbon and nitrogen to marine bacteria, Mar. Ecol. Prog. Ser., 98, 135-148, 1993.

Jørgensen, N. O. G., Tranvik, L., Edling, H., Granéli, E., and Lindell, M.: Effects of sunlight on occurrence and bacterial turnover of specific carbon and nitrogen compounds in lake waters, FEMS Microbiol. Ecol., 25, 217-227, 1998.

Jørgensen, N. O. G., Kroer, N., Coffin, R. B., and Hoch, M. P.: Relations between bacterial nitrogen metabolism and growth efficiency in an estuarine and an open-water ecosystem, Aquat. Microb. Ecol., 18, 247-261, 1999.

Keil, R. G. and Kirchman, D. L.: Contribution of dissolved free amino acids and ammonium to the nitrogen requirements of heterotrophic bacterioplankton, Mar. Ecol. Prog. Ser., 73, 1-10, 1991.

Kieber, D. J.: Photochemical production of biological substrates, in: The effects of UV radiation in the marine environment, edited by: de Mora, S., Demers S., and Vernet, M., Cambridge University Press, Cambridge, pp. 131-148, 2000.

Kirchman, D. L., Keil, R. G., and Wheeler, P. A.: The effect of amino acids on ammonium utilization and regeneration by heterotrophic bacteria in the subarctic Pacific, Deep-Sea Res., 36, 1763-1776, 1989.

Kirchman, D. L., Suzuki, Y., Garside, C., and Ducklow, H. W.: High turnover rates of dissolved organic carbon during a spring phytoplankton bloom, Nature, 352, 612-614, 1991.

Kirchman, D. L., Moss, J., and Keil, R. G.: Nitrate uptake by heterotrophic bacteria: Does it change the f-ratio?, Arch. Hydrobiol., 37, 129-138, 1992.

Kirchman, D. L. and Wheeler, P. A.: Uptake of ammonium and nitrate by heterotrophic bacteria and phytoplankton in the subArctic Pacific, Deep-Sea Res. I, 45, 347-365, 1998.

Kirchman, D. L.: Uptake and regeneration of inorganic nutrients by marine heterotrophic bacteria, in: Microbial Ecology of the Oceans, edited by: Kirchman, D. L., Wiley-Liss, Inc., New York, pp. 261-288, 2000.

Kivic, P. A. and Vesk, M. J.: Pinocytotic uptake of protein from the reservoir in Euglena, Arch. Microbiol., 96, 155-159, 1974.

Klut, M., Bisalputra, T., and Anita, N. J.: Some observations on the structure and function of the dinoflagellate pusule, Can. J. Botany, 65, 736-744, 1987.

Koopmans, D. J. and Bronk, D. A.: Photochemical production of inorganic nitrogen from dissolved organic nitrogen in waters of two estuaries and adjacent surficial groundwaters, Aqua. Micro. Eco., 26, 295-304, 2002.

Kristiansen, S.: Urea as a nitrogen source for the phytoplankton in the Oslofjord, Mar. Biol., 74(1), 17-24, 1983.

Kroer, N., Jørgensen, N. O. G., and Coffin, R. B.: Utilization of dissolved nitrogen by heterotrophic bacterioplankton: A comparison of three ecosystems, Appl. Env. Microbiol., 60, 4116-4123, 1994.

Kudela, R. W. and Cochlan, W. P.: Nitrogen and carbon uptake kinetics and the influence of irradiance for a red tide bloom off southern California, Aquat. Microb. Ecol., 21, 31-47, 2000.

Langheinrich, U.: Plasma membrane-associated aminopeptidase activities of Chlamydomonas reinhardtii and their biochemical characterization, Biochim. Biophysica Acta, 1249(1), 45-57, 1995.

Lee, C., Hedges, J. I., Wakeham, S. G., and Zhu, N.: Effectiveness of various treatments in retarding microbial activity in sediment trap material and their effects on the collection of swimmers, Limnol. Oceanogr., 37, 117-130, 1992.

Lee, S. and Fuhrman, J. A.: Relationship between biovolume and biomass of naturally derived bacterioplankton, Appl. Env. Microbiol., 53, 1298-1303, 1987.

Lee, S., Kang, Y.-C., and Fuhrman, J. A.: Imperfect retention of natural bacterioplankton cells by glass fiber filters, Mar. Ecol. Prog. Ser., 119, 285-290, 1995.

Legrand, C. and Carlsson, P.: Uptake of high molecular weight dextran by the dinoflagellate Alexandrium catenella, Aquat. Microb. Ecol, 16, 81-86, 1998.

Legrand, C., Granéli, E., and Carlsson, P.: Induced phagotrophy in the photosynthetic dinoflagellate Heterocapsa triquetra, Aquat. Microb. Ecol., 15, 65-75, 1998.

Lewitus, A. J.: Osmotrophy in marine microalgae, in: Algal cultures analogues and blooms, edited by: Subba Rao, D. V., Science Publishers, Inc., Enfield, New Hampshire, 2005.

Li, A., Stoecker, D. K., and Coats, D. W.: Spatial and temporal aspects of Gyrodinium galatheanum in Chesapeake Bay: distribution and mixotrophy, J. Plankton Res., 22, 2105-2124, 2000a.

Li, A., Stoecker, D., and Coats, D.: Mixotrophy in Gyrodinium galatheanum (Dinophyceae); responses to light intensity and inorganic nutrients, J. Phycol., 36, 33-45, 2000 b.

Li, W. K. W.: Primary production of prochlorophytes, cyanobacteria, and eucaryotic ultraphytoplankton: Measurements from flow cytometric sorting, Limnol. Oceanogr., 39, 169-175, 1994.

Libby, P. and Wheeler, P.: Particulate and dissolved organic nitrogen in the central and eastern equatorial Pacific, Deep-Sea Res., 44(2), 345-361, 1997.

Lipschultz, F.: Nitrogen-specific uptake rates of marine phytoplankton isolated from natural populations of particles by flow cytometry, Mar. Ecol. Prog. Ser., 123, 245-258, 1995.

Lomas, M. W.: Nitrate reductase and urease enzyme activity in the marine diatom Thalassiosira weissflogii (Bacillariophyceae): interactions among nitrogen substrates, Mar. Biol., 144, 37-44, 2004.

Lomas, M. W., Glibert, P. M., Berg, G. M., and Burford, M.: Characterization of nitrogen uptake by natural populations of Aureococcus anophagefferens (Chrysophyceae) as a function of incubation duration, substrate concentration, light, and temperature, J. Phycol., 32, 907-916, 1996.

Lomas, M. and Glibert, P.: Temperature regulation of nitrate uptake: A novel hypothesis about nitrate uptake and reduction in coolwater diatoms, Limnol. Oceanogr., 44, 556-572, 1999a.

Lomas, M. W. and Glibert, P. M.: Interactions between $\mathrm{NH}_{4}^{+}$and $\mathrm{NO}_{3}^{-}$uptake and assimilation: Comparison of diatoms and dinoflagellates at several growth temperatures, Mar. Biol., 133, 541-551, 1999b.

Lomas, M. W., Trice, T. M., Glibert, P. M., Bronk, D. A., and McCarthy, J. J.: Temporal and spatial dynamics of urea uptake and regeneration rates and concentrations in Chesapeake Bay, Estuaries, 25, 469-482, 2002.

Lopez-Lozano, A., Diez, J., El Alaoui, S., Moreno-Vivian, C., and Garcia-Fernandez, J. M.: Nitrate is reduced by heterotrophic bacteria but not transferred to Prochlorococcus in non-axenic cultures, FEMS Microbiol. Ecol., 41, 151-160, 2002.

Marie, D., Brussaard, C. P. D., Thyrhaug, R., Bratbak, G., and Vaulow, D.: Enumeration of marine viruses in culture and nat- 
ural samples by flow cytometry, Appl. Env. Microbiol., 65(1), 45-52, 1999.

McCarthy, J. J.: Uptake of urea by natural populations of marine phytoplankton, Limnol. Oceanog., 17, 738-748, 1972a.

McCarthy, J. J.: Uptake of urea by marine phytoplankton, J. Phycol., 8, 216-222, 1972b.

McCarthy, M., Hedges, J., and Benner, R.: Major biochemical composition of dissolved high molecular weight organic matter in seawater, Mar. Chem., 55, 281-297, 1996.

Middelburg, J. J. and Nieuwenhuize, J.: Uptake of dissolved inorganic nitrogen in turbid, tidal estuaries, Mar. Ecol. Prog. Ser., 192, 79-88, 2000a.

Middelburg, J. J. and Nieuwenhuize, J.: Nitrogen uptake by heterotrophic bacteria and phytoplankton in the nitrate-rich Thames estuary, Mar. Ecol. Prog. Ser., 203, 13-21, 2000b.

Monger, B. C. and Landry, M. R.: Flow cytometric analysis of marine bacteria with Hoechst 33342, Appl. Environ. Microbiol., 59, 905-911, 1993

Moore, L. R., Post, A. F., Rocap, G., and Chisholm, S. W.: Utilization of different nitrogen sources by the marine cyanobacteria Prochlorococcus and Synechococcus, Limnol. Oceanogr., 47, 989-996, 2002.

Mulholland, M. and Lomas, M.: Nitrogen uptake and assimilation, in: Nitrogen in the Marine Environment, edited by: Capone, D. G., Bronk, D. A., Mulholland, M., and Carpenter, E. J., Elsevier, San Diego, in press, 2008.

Mulholland, M. R., Glibert, P. M., Berg, G. M., Van Heukelem, L., Pantoja, S., and Lee, C.: Extracellular amino acid oxidation by microplankton: a cross-system comparison, Aquat. Microb. Ecol., 15, 141-152, 1998.

Mulholland, M. R., Gobler, C. J., and Lee, C.: Peptide hydrolysis, amino acid oxidation, and nitrogen uptake in communities seasonally dominated by Aureococcus anophagefferens, Limnol. Oceanogr., 47, 1094-1108, 2002.

Mulholland, M. R., Lee, C., and Glibert, P. M.: Extracellular enzyme activity and uptake of carbon and nitrogen along as estuarine salinity and nutrient gradient, Mar. Ecol. Prog. Ser., 258, $3-17,2003$.

Olson, R. J., Frankel, S. L., and Chisholm, S. W.: An inexpensive flow cytometer for the analysis of fluorescence signals in phytoplankton: Chlorophyll and DNA distributions, J. Exp. Mar. Biol. Ecol., 68, 129-144, 1983.

Olson, R. J., Vaulot, D., and Chisholm, S. W.: Marine phytoplankton distributions measured using shipboard flow cytometry, Deep-Sea Res., 32, 1273-1280, 1985.

Oremland, D. S. and Capone, D.: Use of specific inhibitors in biogeochemistry and microbial ecology, Adv. Microb. Ecol., 10, 285-383, 1988.

Paerl, H. W.: Ecophysiological and trophic implications of lightstimulated amino acid utilization in marine picoplankton, Appl. Environ. Microbiol., 57, 473-479, 1991.

Paerl, H. W.: Coastal eutrophication and harmful algal blooms: importance of atmospheric deposition and groundwater as "new" nitrogen and other nutrient sources, Limnol. Oceanogr., 42, 1154-1165, 1997.

Palenik, B. and Morel, F. M. M.: Comparison of cell-surface Lamino acid oxidases from several marine phytoplankton, Mar. Ecol. Prog. Ser., 59, 195-201, 1990a.

Palenik, B. and Morel, F. M. M.: Amino acid utilization by ma- rine phytoplankton: A novel mechanism, Limnol. Oceanogr., 35 , 260-269, 1990b.

Palenik, B. and Morel, F. M. M.: Amine oxidases of marine phytoplankton, Appl. Environ. Microbiol., 57, 2440-2443, 1991.

Palenik, B., Brahamsha, B., Larimer, F. W., Land, M., Hauser, L., Chain, P., Lamerdin, J., Regala, W., Allen, E. E., McCarren, J., Paulsen, I., Dufresne, A., Partensky, F., Webb, E. A., and Waterbury, J.: The genome of a motile marine Synechococcus, Nature, 424, 1037-1042, 2003.

Pantoja, S. and Lee, C.: Cell-surface oxidation of amino acids in seawater, Limnol. Oceanogr., 39, 1718-1726, 1994.

Pehlivanoglu-Mantas, E. and Sedlak, D. L.: Wastewater-Derived Dissolved Organic Nitrogen: Analytical Methods, Characterization, and Effects: A Review, Crit. Rev. Env. Sci. Technol., 36, 261-285, 2006.

Pel, R., Floris, V., Gons, H. J., and Hoogveld, H. L.: Linking flow cytometric cell sorting and compound-specific ${ }^{13} \mathrm{C}$-analysis to determine population-specific isotopic signatures and growth rates in cyanobacteria-dominated lake plankton, J. Phycol., 40, 857-866, 2004.

Peuravuori, J., Lohtonen, T., and Pihlaja, K.: Sorption of aquatic humic matter by DAX-8 and XAD- 8 resins. Comparative study using pyrolysis gas chromatography, Anal. Chim. Acta, 471, 219-226, 2002.

Radajewski, S., Ineson, P., Parekj, N. R., and Murrell, J. C.: Stableisotope probing as a tool in microbial ecology, Nature, 403, 646649, 2000

Rashid, M. A.: Contribution of humic substances to the cation exchange capacity of different marine sediments, Maritime Sediments, 5, 44-50, 1969.

Rashid, M. A.: Geochemistry of Marine Humic Compounds, Springer, New York, 1985.

Reckermann, M.: Flow sorting in aquatic ecology, Scientia Marina, 64, 235-246, 2000.

Repeta, D. J., Quan, T. M., Aluwihare, L. I., and Accardi, A. M.: Chemical characterization of high molecular weight dissolved organic matter in fresh and marine waters, Geochim. Cosmochim. Acta, 66(6), 955-962, 2002.

Rivkin, R. B., Phinney, D. A., and Yentsch, C. M.: Effects of flow cytometric analysis and cell sorting on photosynthetic carbon uptake by phytoplankton in cultures and from natural populations, Appl. Environ. Microbiol., 52, 935-938, 1986.

Rocap, G., Larimer, F., Lamerdin, J., Malfatti, S., Chain, P., Ahlgren, N., Arellano, A., Coleman, M., Hauser, L., Hess, W., Johnson, Z., Land, M., Lindell, D., Post, A., Regala, W., Shah, M., Shaw, S., Steglich, C., Sullivan, M., Ting, C., Tolonen, A., Webb, E., Zinser, E., and Chisholm, S. W.: Genome divergence in two Prochlorococcus ecotypes reflects oceanic niche differentiation, Nature, 424, 1042-1047, 2003.

Rodrigues, R. M. N. V. and Williams, P. J. B.: Inorganic nitrogen assimilation by picoplankton and whole plankton in a coastal ecosystem, Limnol. Oceanogr., 47, 1608-1616, 2002.

Rosenfeld, J. K.: Ammonium adsorption in nearshore anoxic sediments, Limnol. Oceanogr., 24, 356-364, 1979.

Sanders, R. and Porter, K.: Phagotrophic phytoflagellates, Adv. Microb. Ecology, 10, 167-192, 1988.

Schnitzer, M.: Nature of nitrogen in humic substances, in: Humic substances in soil, sediment, and water, edited by: Aiken, G. R., McKnight, D. M., and Wershaw, R. L., John Wiley and Sons, 
New York, pp. 303-328, 1985.

See, J. H.: Availability of humic nitrogen to phytoplankton, Ph.D. Dissertation, Physical Sciences, The College of William and Mary, Williamsburg, pp. 164, 2003.

See, J. H. and Bronk, D. A.: Changes in molecular weight distributions, $\mathrm{C}: \mathrm{N}$ ratios, and chemical structures of estuarine humic substances with respect to season and age, Mar. Chem., 97, 334346, 2005.

See, J. H., Bronk, D. A., and Lewitus, A. J.: Uptake of Spartinaderived humic nitrogen by estuarine phytoplankton in axenic and non-axenic culture, Limnol. Oceanogr., 51, 2290-2299, 2006.

Seitzinger, S. and Sanders, R.: Contribution of dissolved organic nitrogen from rivers to estuarine eutrophication, Mar. Ecol. Prog. Ser., 159, 1-12, 1997.

Sinsabaugh, R. L., Findlay, S., Franchini, P., and Fischer, D.: Enzymatic analysis of riverine bacterioplankton production, Limnol. Oceanogr., 42, 29-38, 1997.

Smalley, G., Coats, D., and Adam, E.: A new method using fluorescent microspheres to determine grazing on ciliates by the mixotrophic dinoflagellate Ceratium furca, Aquat. Microb. Ecol., 17, 167-179, 1999.

Smayda, T. J.: Harmful algal blooms: Their ecophysiology and general relevance to phytoplankton blooms in the sea, Limnol. Oceanogr., 42, 1137-1153, 1997.

Stepanauskas, R., Laudon, H., and Jørgensen, N. O. G.: High DON bioavailability in boreal streams during a spring flood, Limnol. Oceanogr., 45, 1298-1307, 2000.

Stephens, G. C. and North, B. B.: Extrusion of carbon accompanying uptake of amino acids by marine phytoplankters, Limnol. Oceanogr., 16, 752-757, 1971.

Stoecker, D. K., Li, A., Coats, D. W., Gustafson, D. E., and Nannen, M. K.: Mixotrophy in the dinoflagellate Prorocentrum minimum, Mar. Ecol. Prog. Ser., 152, 1-12, 1997.

Stoecker, D. K. and Gustafson, D. E.: Cell-surface proteolytic activity of photosynthetic dinoflagellates, Aquat. Microb. Ecol., 30, 175-183, 2003.

Syrett, P. J.: Uptake and utilization of nitrogen compounds, in: Biochemistry of the Algae and Cyanobacteria, edited by: Rogers, L. J. and Gallon, J. R., Oxford University Press, New York, pp. 2339, 1988.

Tamminen, T. and Irmisch, A.: Urea uptake kinetics of a midsummer planktonic community on the SW coast of Finland, Mar. Ecol. Prog. Ser., 130, 201-211, 1996.

Thurman, E. M., Wershaw, R. L., Malcolm, R. L., and Pinckney, D. J.: Molecular size aquatic humic substances, Organic Geochem., 4, 27-35, 1982.
Thurman, E. M.: Organic Geochemistry of Natural Waters, Niyhoff/Junk, Boston, 1985.

Veldhuis, M. J. W. and Kraay, G. W.: Application of flow cytometry in marine phytoplankton research: current applications and future perspectives, Scientia Marina, 64, 121-134, 2000.

Veuger, B., Middelburg, J. J., Boschker, H. T. S., Nieuwenhuize, J., van Rijswijk, P., Rocchelle-Newall, E. J., and Navarro, N.: Microbial uptake of dissolved organic and inorganic nitrogen in Randers Fjord, Est. Coast. Shelf Sci., 61, 507-515, 2004.

Vives-Rego, J., Lebaron, P., and Nebe-von Caron, G.: Current and future applications of flow cytometry in aquatic microbiology, FEMS Microbiol. Rev., 24, 429-448, 2000.

Wallner, G., Fuchs, B., Spring, S., Beisker, W., and Amann, R.: Flow sorting of microorganisms for molecular analysis, Appl. Environ. Microb., 63, 4223-4231, 1997.

Wheeler, P. A. and Kirchman, D. L.: Utilization of inorganic and organic nitrogen by bacteria in marine systems, Limnol. Oceanogr., 31, 998-1009, 1986.

Wheeler, P. A., North, B. B., and Stephens, G. C.: Amino acid uptake by marine phytoplankters, Limnol. Oceanogr., 19, 249259, 1974.

Wheeler, P. A., North, B., Littler, M., and Stephens, G.: Uptake of glycine by natural phytoplankton communities, Limnol. Oceanogr., 22, 900-910, 1977.

Wiegner, T. N., Seitzinger, S. P., Glibert, P., and Bronk, D. A.: Bioavailability of dissolved organic nitrogen and carbon from nine rivers in the Eastern United States, Aquat. Microb. Ecol., 43, 277-287, 2006.

Yentsch, C. M., Horan, P. K., Muirhead, K., Dortch, Q., Haugen, E., Legendre, L., Murphy, L. S., Perry, M. J., Phinney, D. A., Pomponi, S. A., Spinrad, R. W., Wood, M., Yentsch, C. S., and Zahuranec, B. J.: Flow cytometry and cell sorting: A technique for analysis and sorting of aquatic particles, Limnol. Oceanogr., 28, 1275-1280, 1983.

Zehr, J. P. and Ward, B. B.: Nitrogen cycling in the ocean: new perspectives on processes and paradigms, Appl. Environ. Microb., 68, 1015-1024, 2002.

Zinser, E. R., Coe, A., Johnson, Z. I., Martiny, A. C., Fuller, N. J., Scanlan, D. J., and Chisholm, S. W.: Prochlorococcus ecotype abundances in the North Atlantic Ocean as revealed by an improve quantitative PCR method, Appl. Environ. Microb., 72, 723-732, 2006.

Zubkov, M. V. and Tarran, G. A.: Amino acid uptake of Prochlorococcus spp. in surface waters across the South Atlantic Subtropical Front, Aquat. Microb. Ecol., 40, 241-249, 2005. 